\title{
Religiousness and happiness in three nations: a research note
}

\author{
Liesbeth Snoep
}

Published online: 6 February 2007

(C) Springer Science+Business Media B.V. 2007

\begin{abstract}
Several empirical investigations have found positive correlations between religiousness and happiness and this is typically seen as a proof of a universal beneficial effect of religion. Yet most studies were done in the USA and the balance of effects may be different in other countries, in particular in countries where the social and economic functions of churches are less prominent and where believers are in the minority. This hypothesis was checked in an analysis of the World Values Survey in three countries: the USA, the Netherlands and Denmark in 2000. Seven self report indicators of religiousness were used. Happiness was measured using a single question on life-satisfaction. The correlations between religiousness and happiness appear to be positive but weak. The correlations are stronger in the USA (average +0.13 , most significant) than in The Netherlands (average +0.05 , none significant) and Denmark (average +0.05 , none significant). The pattern of correlation is not much different among people who might benefit more from the support of religion, such as widows. Apparently religiousness is not always a blessing.
\end{abstract}

\section{Introduction}

There is a large literature on effects of religion on personal wellbeing, a review by Koenig, McCullough, and Larson (2001) covers more than a thousand investigations, many of which report positive effects of religion on mental and physical health. In this line Lehrer (2004) wrote recently that:

Based on Master Thesis 'Religie en geluk: gaat dat samen?' supervised by Prof. Dr. R. Veenhoven, Department of Sociology, Erasmus University Rotterdam, The Netherlands

L. Snoep $(\square)$

Department of Social Sciences, c/o Ruut Veenhoven, Erasmus University Rotterdam, POB 1738, Rotterdam 3000DR, The Netherlands

e-mail: Veenhoven@fsw.eur.nl 
"There is considerable evidence that religion makes a difference to people's lives: it provides social networks, favourably affects physical and mental health, school attendance and reduces deviant activity."

Part of this literature deals with effects of religiousness on happiness. Several empirical investigations into that relationship found positive correlations (e.g. Blazer \& Palmore, 1976; Hadaway, 1978; Moberg, 1979). In this line Luttmer (2005) observed that:

"It is typically found that religious activities and beliefs are positively correlated with measures of subjective well-being, even controlling for demographic variables, such as age, income and marital status." In the same vein Clark and Lelkes (2005) write:

"Religious people are more satisfied, even when controlling for social capital and for being a crime victim, and other personal characteristics."

In this journal Ferriss (2002) reported that happiness is associated with the frequency of attendance at religious services, with denominational preference, and with doctrinal preference. Happiness appeared also associated with certain religious-related beliefs: belief that the world is evil or good but not belief in immortality. Likewise Cohen (2002) reported in this journal: "In different samples and with different measures, congregational support and public practice of religion appear to correlate similarly with measures of life satisfaction for members of different religions." In this journal Swinyard (2001) reported that happiness is positively related to 'intrinsic' religion, but not to 'extrinsic' religion or religion as a 'quest'.

This observed correlation between religiousness and happiness is usually attributed to positive functions of religion, such as providing meaning and social support. Yet religion can also involve negative effects. Ellis (1962) states that: "Excessive religion can produce depression or other mental disorders in some individuals."

Most authors implicitly imply that the beneficial (net) effect of religion is universal. Yet one can also imagine that functions are context dependent, for instance that (a) economic support by churches is more important for the happiness of their members in residual welfare states, (b) social support by churches is more important in countries where geographical mobility is high, and (c) that the message is more convincing in countries where the majority of compatriots share the belief.

In this context it is worth noting that most investigations on the relation between religion and happiness have been carried out in the USA and that this country fits all three conditions mentioned. The balance of effects may be different in a country like The Netherlands, where the state has a greater share in social security, people live less far from their relatives and where believers are in the minority.

\section{Method}

This hypothesis was checked using data of the most recent World Values Survey in three nations: Denmark, The Netherlands and the USA. Denmark had been chosen as a double check for The Netherlands. Denmark is, like The Netherlands, a secularised, small, West-European country where the state has a great share in social security.

The World Values Survey was used because it contains identical questions for those three countries so that eventual differences could not be attributed to 
differences in measurement. A second reason for using the WVS is that its surveys are based on representative samples of the whole population and does not restrict to special publics, such as students, as most of the earlier studies do. But the most important reason to use the WVS is because it contains detailed data on religiousness and also had indicators for happiness.

Happiness was measured using a single question on life-satisfaction: how satisfied are you with your life ? $^{1}$ Respondents had to answer this question with a number: one (unhappy) to ten (happy).

The following indicators of religiousness were used: time spend with people at your church, belong to a church organisation, belong to religious denomination, how often someone attends religious service, the importance of God in someone's life, moments of prayer/meditation, pray to God outside of religious service.

\section{Results}

Bi-variate correlational analysis shows positive but weak relationships between religiousness and happiness. The correlations are stronger in the USA (average +0.13 ) than in The Netherlands (average +0.05$)$ and Denmark (average +0.05$)$. In the USA, most of the correlations reach statistical significance, except moments of prayer/meditation and pray to God outside of religious service. In Denmark and the Netherlands none of the correlations is significant.

Correlation coefficients reflect a linear relationship and can be misleading in the case of a non-linear pattern. Therefore, all the relationships were visually inspected using bar-charts and flower-plots, but this did not reveal any non-linear patterns.

These correlations reflect the effect of religiousness on the happiness of the average citizen. Possibly the effect is more pronounced in specific categories. One might expect that religiousness has a greater effect on the happiness of people who are in need of social and emotional support, such as elderly people, widows, low educated people and the unemployed. Therefore the above correlations were also computed for each of these subgroups separately. In the USA the correlations in the subgroup analyses were positive and most were significant. In The Netherlands and Denmark religiousness was not correlated either among elderly people, widows, low educated or unemployed people.

Which aspects of religion add most to happiness? The correlations in Scheme 1 suggest that the social aspects are more important than the private experience of religion, the correlations with church participation being stronger than the correlations with praying, meditation and belief in God. This was confirmed in a multivariate analysis. Time spend with people at your church appeared to be the strongest predictor of happiness in the USA and belong to a church organisation the most important factor in Denmark and the Netherlands.

\footnotetext{
${ }^{1}$ Numbers of the variables in The World Values Survey 2000: A170 how satisfied are you with your life. A060 spend time with people at your church. A065 belong to church organisation. F024 belong to religious denomination. F028 (recoded) how often you attend religious service. F063 how important is God in your life. F065 moments of prayer/meditation F066 pray to God outside of religious service.
} 
Scheme 1 Association of religion and happiness in 2000 in The Netherlands, Denmark and the USA

\begin{tabular}{|c|c|c|c|c|}
\hline \multirow[t]{2}{*}{ Indicators of religiousness } & \multicolumn{4}{|c|}{ Association with happiness } \\
\hline & $\begin{array}{l}\text { Measure of } \\
\text { association }\end{array}$ & Netherlands & Denmark & USA \\
\hline $\begin{array}{l}\text { Spend time with people at } \\
\text { your church: weekly, } \\
\text { once or twice a month, } \\
\text { only a few times a year, } \\
\text { not at all }\end{array}$ & Kendall's tau-c & +0.028 & +0.008 & $+0.188^{\mathrm{a}}$ \\
\hline $\begin{array}{l}\text { Belong church } \\
\text { organisation: not } \\
\text { mentioned, belong to } \\
\text { a church organisation }\end{array}$ & Cramer's V & +0.134 & +0.105 & $+0.196^{\mathrm{a}}$ \\
\hline $\begin{array}{l}\text { Belong to religious } \\
\text { denomination: not } \\
\text { mentioned, belong to } \\
\text { religious denomination }\end{array}$ & Cramer's V & +0.063 & +0.080 & $+0.143^{\mathrm{a}}$ \\
\hline $\begin{array}{l}\text { How often do you attend } \\
\text { religious service: } \\
\text { (practically) never, more } \\
\text { often than '(practically) } \\
\text { never', once a year, other } \\
\text { specific holy days, only } \\
\text { on special holy days/ } \\
\text { Christmas/Easter, once a } \\
\text { month, once a week, } \\
\text { more than once a week }\end{array}$ & Kendall's tau-c & +0.037 & +0.029 & $+0.153^{\mathrm{a}}$ \\
\hline $\begin{array}{l}\text { How important is God in } \\
\text { your life: one (=not at } \\
\text { all) - ten (=very } \\
\text { important) }\end{array}$ & Kendall's tau-c & -0.004 & +0.035 & $+0.097^{\mathrm{a}}$ \\
\hline $\begin{array}{l}\text { Moments of prayer, } \\
\text { meditation: no I don't } \\
\text { have moments of prayer/ } \\
\text { meditation, yes I do have } \\
\text { moments of prayer/ } \\
\text { meditation }\end{array}$ & Cramer's V & +0.106 & +0.091 & +0.083 \\
\hline $\begin{array}{l}\text { Pray to God outside of } \\
\text { religious service: every } \\
\text { day, more than once a } \\
\text { week, once a week, at } \\
\text { least once a month, } \\
\text { several times a year, less } \\
\text { often, never }\end{array}$ & Kendall's tau-c & +0.008 & +0.003 & -0.071 \\
\hline Average correlation & & +0.054 & +0.050 & +0.133 \\
\hline
\end{tabular}

a $P<0.05$

\section{Conclusion}

Apparently, the effects of religion on happiness are not the same everywhere and the balance of effects not always positive. Hence the question in further research should not be whether religiousness boosts happiness, but in what conditions for what people. 


\section{References}

Blazer, D., \& Palmore, E. B. (1976). Religion and aging. Gerontologist, 16, 82-85.

Clark, A. E., \& Lelkes, O. (February 2005). Let us pray: Religious interactions in life satisfaction. (Paris/Vienna).

Cohen, A. B. (2002). The importance of spirituality in well-being for Jews and Christians. Journal of Happiness Studies, 3, 287-310.

Ellis, A. (1962). Reason and emotion in psychotherapy New York: Lyle Stuart.

Ferriss, A. L. (2002).Religion and the quality of life. Journal of Happiness Studies, 3, 199-215.

Hadaway, C. K. (1978). Life Satisfaction and Religion. Social Forces, 57, 636-643.

Koenig, H. G., McCullough, M. E., \& Larson, D. B. (2001). Handbook of religion and health Oxford: University Press.

Lehrer, E. (2004). Religion as a determinant of economic and demographic behaviour in the United States. Population and Development Review, 30, 707-726.

Luttmer, E. (2005). Neighbours as negatives: Relative earnings and well-being. Quarterly Journal of Economics, 120, 963-1002.

Moberg, D. O. (Ed.). (1979). Spiritual Well-Being. Washington. D.C.: University Press of America.

Swinyard, W. R., Kau, A.-K., \& Phua, H.-Y. (2001). Happiness, materialism, and religious experience in the US and Singapore. Journal of Happiness Studies, 2, 13-32.

World Values Survey. Http://www.worldvaluessurvey.org/. 